\title{
CORRELATION BETWEEN AGE AND BASAL DIAMETER OF FRAXINUS ORNUS L. IN THREE ECOLOGICALLY CONTRASTING HABITATS
}

\author{
P. CSONTOS ${ }^{1}$, J. TAMÁS ${ }^{2}$ and T. KALAPOS ${ }^{3}$ \\ ${ }^{1}$ Research Group in Theoretical Biology and Ecology, MTA-ELTE \\ H-1117 Budapest, Pázmány P. sétány 1/c, Hungary; E-mail: cspeter@ludens.elte.hu \\ ${ }^{2}$ Inst. Ecology and Botany, Hungarian Academy of Sciences \\ H-2163 Vácrátót, Alkotmány u. 2-4, Hungary \\ ${ }^{3}$ Dept Plant Taxonomy and Ecology, L. Eötvös University \\ H-1117 Budapest, Pázmány P. sétány 1/c, Hungary
}

(Received 3 October, 2000)

\begin{abstract}
Manna ash (Fraxinus ornus L.) is a typical deciduous tree of South European distribution reaching the northern border of its range in the Carpathian Basin. The correlation between age and basal diameter of this tree was analysed in three ecologically contrasting habitats, as follows. (1) Successional habitat. Abandoned farmland with scattered occurrence of manna ash as a colonising tree of the area. (2) Austrian pine plantation, where manna ash often forms a spontaneous subordinate tree or shrub layer. (3) Cotino-Quercetumpubescentis, the natural vegetation on south facing calcareous hillslopes in Hungary, where Quercus pubescens Willd. and Fraxinus ornus codominate in the low canopy. At each sampling site 21 individuals were selected with an even distribution within circumference categories ranging from $6 \mathrm{~cm}$ to $60 \mathrm{~cm}$. Circumference measurements were made at the base of the tree-trunks, then either the tree was felled and a $1 \mathrm{~cm}$ thick disk was cut off from the trunk, or cores were taken by a driller. Linear regression analysis was applied to test the correlation between age and diameter.

Average age for the measured individuals was 19.76 years in the successional habitat, 37.76 years in the pine plantation and 33.67 years in the Cotino-Quercetum pubescentis community. Significant correlation $(p<0.001)$ appeared between basal diameter and age (yearring count) in the successional habitat and the pine plantation with regression coefficients $r=0.7406$ and $r=0.9181$, respectively. In case of the Cotino-Quercetum pubescentis community age and basal diameter varied almost independently $(r=0.2712)$. Taking slope angles of regression equations into account, trees grow $72 \%$ faster in average in the successional habitat than in the pine plantation. In conclusion the basal diameter of the trunk was found to be a good predictor of tree age where populations develop under a relatively uniform light regime. However, the highly heterogeneous aerial and soil environments in the species' typical natural habitat cause an uncoupling of age and trunk diameter.
\end{abstract}

Key words: basal diameter, Fraxinus ornus, manna ash, plasticity, tree age, year-ring counts

* The authors dedicate this paper to Professor Gábor Fekete for his 70th birthday. 


\section{INTRODUCTION}

Manna ash (Fraxinus ornus L.) is a typical deciduous tree of South European distribution with special importance in the vegetation of the East Mediterranean Basin (Horvat et al. 1974). Its area ranges from eastern Spain to the southern coastal area of Turkey and from Sicily and Peloponnesos to the Carpathian Basin (Kárpáti 1970, Meusel et al. 1978). Beyond this range it is known as naturalized tree from Barcelona and Burgos (Spain) regions (Baonza et al. 1995), from south France, from Crimea and from some other localities between the latitudes $45^{\circ}$ and $50^{\circ}$. Recently its rapid invasion in the Hérault River system (France) was analysed by Thébaud and Debussche (1991).

Hungarian populations of manna ash are at the northern border of the distribution range, though its northernmost, sporadic occurrences are found in Slovakia (Bertová et al. 1984). In spite of the peripheral position regarding the area of the species it is widespread in Transdanubia (Hungary) (Szabó 1939) and occurs in several community types from the xerotherm rock grasslands to the more humid beech forests. Selected examples for coenological behaviour of manna ash are shown in Table 1, whereas a complete list of Hungarian community types with this species is given by Soó (1966). The morphological variability of the Hungarian populations is also notable (Kárpáti 1958).

The considerable plasticity of this species is obvious from the records above, but its growth rate and biomass production can be very different under various circumstances. Our interest in this paper is focused on the correlation between age and thickness of individual trees and its variation among manna ash populations growing on ecologically contrasting habitats.

\section{MATERIALS AND METHODS}

Three study sites were selected in the Buda Hills and its surroundings:

1. Successional habitat. Abandoned farmland, mainly covered by grassland vegetation with scattered occurrence of Fraxinus ornus as a colonising tree of the area. Additional woody species are: Rosa canina L., Crataegus monogyna Jacq., Cornus sanguinea L. and Ailanthus altissima (Mill.) Swingle. In this situation manna ash individuals are standing far from each other, thus exposed to full sun. Locality: Nyakas Hill, near the village Tök; altitude: $280-290 \mathrm{~m}$ a.s.l.; slope: $5-7^{\circ}$, facing east-southeast. 
2. Pine plantation. In the middle of the 20th century many of the overgrazed hillslopes throughout the Hungarian Mountain Range were afforested with Pinus nigra, an introduced tree in Hungary. On the area consisting our study site afforestation was carried out in the early fifties. Nowadays the average height of these stands is $14-16 \mathrm{~m}$, with a density of 0.16 pine individuals/square metre. In these pine forests Fraxinus ornus often forms a spontaneous subordinate tree or shrub layer (see Table 1), with a poorly developed low diversity herb layer (Borhidi 1956, Csontos et al. 1996). Fraxinus individuals are subjected considerable shade under the closed canopy of Pinus nigra (in an overcast summer day only $10 \%$ of the incoming diffuse radiation reaches the pine plantation floor), and this habitat is more humid than the other two. Worth for mentioning that in the Balkan Peninsula Pinus nigra and Fraxinus ornus naturally form mixed-

Table 1

Coenological behaviour of Fraxinus ornus in selected community types in Hungary. A-D = combined scale for abundance and dominance; $\mathrm{K}=$ constancy value; $\mathrm{A}=$ tree layer; $\mathrm{B}=$ shrub layer; $\mathrm{C}=$ herb layer; ${ }^{*}=$ frequency value

\begin{tabular}{|c|c|c|c|c|}
\hline Community type & A-D & $\mathrm{K}$ & Remark & Reference \\
\hline Fageto-Ornetum hungaricum & $2-4$ & $\mathrm{~V}$ & & Zólyomi 1958 \\
\hline Orneto-(Lithospermo-) & & & & \\
\hline Quercetum praeillyrico-matricum & 2 & $\mathrm{~V}$ & & Zólyomi 1958 \\
\hline $\begin{array}{l}\text { Cotino-Quercetum pubescentis } \\
\text { balatonicum }\end{array}$ & $1-4$ & $\mathrm{~V}$ & & Zólyomi 1958 \\
\hline $\begin{array}{l}\text { Orno-Quercetum pubescenti-cerris } \\
\text { pannonicum }\end{array}$ & +-4 & $\mathrm{~V}$ & $\begin{array}{l}\text { both in layer } \\
\mathrm{A} \text { and } \mathrm{B}\end{array}$ & Debreczy 1968 \\
\hline $\begin{array}{l}\text { Querceto-Lithospermetum cult. consoc. } \\
\text { Pinus nigra }\end{array}$ & +-3 & $\mathrm{~V}$ & fewer in layer $\mathrm{A}$ & Borhidi 1956 \\
\hline $\begin{array}{l}\text { Orno-Quercetum pubescentis } \\
\text { Mecsekense }\end{array}$ & +-3 & $\mathrm{~V}$ & & Horváth 1972 \\
\hline $\begin{array}{l}\text { Mahalebeto-Quercetum pubescentis } \\
\text { calcareum }\end{array}$ & +-3 & $\mathrm{~V}$ & & Zólyomi 1958 \\
\hline Corno-Quercetum & +-3 & $\mathrm{~V}$ & fewer in layer B & Horánszky 1964 \\
\hline $\begin{array}{l}\text { Cotino-Quercetum pubescentis } \\
\text { Mecsekense }\end{array}$ & +-2 & $\mathrm{~V}$ & & Horváth 1972 \\
\hline Ceraso-Quercetum & +-2 & $\mathrm{~V}$ & $\mathrm{~K}=\mathrm{IV}$ in layer $\mathrm{B}$ & Horánszky 1964 \\
\hline Orno-Quercetum & +-3 & IV & $\mathrm{K}=\mathrm{V}$ in layer $\mathrm{B}$ & Horánszky 1964 \\
\hline Querceto-Lithospermetum & +-2 & IV & $\begin{array}{l}\text { both in layer } \\
\mathrm{A} \text { and B }\end{array}$ & Fekete 1956 \\
\hline Festuco-Brometum erecti archimatricum & +-1 & IV & in layer C & Tamás 1997 \\
\hline Quercetum petraeae-cerris & $1-2$ & IV & in layer B only & Penksza et al. 1996 \\
\hline Genisto pilosae-Quercetum & +-2 & III & fewer in layer B & Horánszky 1964 \\
\hline Helleboro dumetorum-Carpinetum & +-2 & III & in layer B & Borhidi 1984 \\
\hline
\end{tabular}




\begin{tabular}{|c|c|c|c|c|}
\hline Community type & A-D & K & Remark & Reference \\
\hline Vicio (oroboidi)-Fagetum & +-2 & III & in layer B & Borhidi 1984 \\
\hline $\begin{array}{l}\text { Seseleo leucospermi-Festucetum pallentis } \\
\text { brometosum pannonici }\end{array}$ & +-1 & III & in layer C & $\begin{array}{l}\text { Mészáros-Dras- } \\
\text { kovits } 1967\end{array}$ \\
\hline Querco-Carpinetum Tilietosum argenteae & +-1 & III & $\begin{array}{l}\text { occasionally in } \\
\text { layers } B \text { and } C\end{array}$ & Horváth 1972 \\
\hline $\begin{array}{l}\text { Potentillo albae-Quercetum (petraeae-cerris) } \\
\text { pannonicum }\end{array}$ & +-1 & III & in layer B only & Zólyomi 1958 \\
\hline Fagetum silvaticae Mecsekense & +-1 & III & & Horváth 1972 \\
\hline Mercuriali-Tilietum & 2 & II & in layer B & Isép \\
\hline Querco (petraeae)-Carpinetum pannonicum & +-1 & II & in layer B & Fekete 1965 \\
\hline Quercetum petraeae-cerris pannonicum & +-1 & II & in layer B & Feke \\
\hline Festucetum glaucae cult. consoc. Pinus nigra & +-1 & II & in layer B & Borhidi 1956 \\
\hline Dictamno-Tilietum cordatae & +-1 & II & in layer B & Fekete 1965 \\
\hline Caricetum humilis cult. consoc. Pinus nigra & +-1 & II & in layer B & Borhidi 1956 \\
\hline $\begin{array}{l}\text { Cleistogeno-Festucetum rupicolae } \\
\text { festucetosum rupicolae }\end{array}$ & + & II & in la & Penksza et al. 1995 \\
\hline Deschampsio-(Luzulo-) Fagetum Mecsekense & + & II & $\begin{array}{l}\text { with reduced } \\
\text { rate in layer } \\
B \text { and C }\end{array}$ & Horváth 1972 \\
\hline Corno-Quercetum Matricum & + & II & in layer A only & Fekete 1965 \\
\hline $\begin{array}{l}\text { Aceri (campestri)-Quercetum petraeae-roboris } \\
\text { Mercuriali-Tilietum Ruscetosum aculeati }\end{array}$ & + & II & in layer B & Fekete 1965 \\
\hline & 2 & I & & h 1972 \\
\hline Asplenio rutae-murariae-Melicetum ciliatae & + & I & in layer C & Penksza et al. 1995 \\
\hline Querco petraeae-Carpinetum & + & I & A and B layers & Horánszky 1964 \\
\hline Luzulo-Quercetum & + & I & A and B layers & Horánszky 1964 \\
\hline
\end{tabular}

canopy stands (Fekete 1959, Horvat et al. 1974). Locality: Zsíros Hill, Buda Hills; altitude: $360-380 \mathrm{~m}$ a.s.l.; slope: $30-35^{\circ}$, facing north.

3. Cotino-Quercetumpubescentis. This community is the natural vegetation on south facing, calcareous hillslopes in Hungary. Here Quercus pubescens and Fraxinus ornus codominate forming a tree canopy with 40-70\% cover. Detailed phytosociological description of this vegetation type is given by Zólyomi (1958). Manna ash individuals receive much more sunshine than under the pine stand, however, they are somewhat shaded by neighbouring Quercus and Fraxinus trees. Water shortage may prevail more often than the other two sites, because considerable surface run off due to the slopes with rock outcrops. Locality: Ördög-orom, Buda Hills; altitude: $260-280 \mathrm{~m}$ a.s.l.; slope: $20-40^{\circ}$, facing east-southeast.

At each sampling site 21 manna ash individuals were selected with an even distribution within prefixed circumference categories ranging from 6 
$\mathrm{cm}$ to $60 \mathrm{~cm}$. Trees with larger circumference than $60 \mathrm{~cm}$ were rare in the studied habitats. Circumference measurements were made at the base of the tree-trunks, but conical parts caused by the branching main roots were omitted. Diameter at brest height - traditionally measured by foresters was not appropriate in this case, because several individuals branched more close to the soil surface. After measuring the circumference the tree was normally felled and a $1 \mathrm{~cm}$ thick disk was cut off from the point where the circumference was measured. Disks were labelled then transported to the laboratory and the year-rings were counted by the aid of appropriate microscope. In case of the thickest individuals the cores were taken by a driller. Because of uncertainty due to year-ring anomalies (Lorimer et al. 1999), counts were repeated three times for disks and twice for cores in different directions, then the average value was calculated for each tree. Disks were considered completely circular for calculating diameter values, then diameter data were plotted against year-ring counts (i.e. age of manna ash individuals). Linear regression analysis was applied to test the correlation between age and diameter (Sváb 1981).

\section{RESULTS AND DISCUSSION}

Basic data for basal diameters and year-ring counts are shown in Table 2. Average ages of the measured individuals were 19.76 years for the successional habitat, 37.76 years in the pine plantation and 33.67 years in the Cotino-Quercetum pubescentis community. The relatively low average age obtained for the successional habitat - considering that the same circumference categories were filled up at every site - highlight the higher growth rate of manna ash individuals at this habitat.

Significant correlation appeared, at $\mathrm{p}<0.001$ level, between basal diameter and age (year-ring count) in the successional habitat and the pine plantation (Figs 1 and 2). The highest regression coefficient $(r=0.9181)$ was found in pine plantation, probably as a result of the uniform conditions prevailing for manna ash growth under the Pinus nigra canopy (Fig. 2). In the successional habitat the data were somewhat more scattered, but the correlation coefficient was still high enough for significance $(r=0.7406)$. At this site there were several examples when a thin tree was older than other individuals found in one or two circumference classes higher (Fig. 1). Presumably, this size and age plasticity can be interpreted as a buffer mechanism against spatial and temporal variability in habitat conditions (Grime 
Table 2

Basal diameter and year-ring counts data of Fraxinus ornus individuals from three ecologically contrasting habitats

\begin{tabular}{|c|c|c|c|c|c|c|c|}
\hline \multirow[t]{2}{*}{ Nr. } & \multirow[t]{2}{*}{$\begin{array}{l}\text { Circumfer- } \\
\text { ence class } \\
(\mathrm{cm})\end{array}$} & \multicolumn{2}{|c|}{$\begin{array}{l}\text { Successional habitat } \\
\text { (Nyakas Hill) }\end{array}$} & \multicolumn{2}{|c|}{$\begin{array}{l}\text { Pine plantation } \\
\text { (Zsíros Hill) }\end{array}$} & \multicolumn{2}{|c|}{$\begin{array}{l}\text { Cotino-Quercetum } \\
\text { pubescentis } \\
\text { (Ördög-orom) }\end{array}$} \\
\hline & & $\begin{array}{l}\text { Diameter } \\
(\mathrm{cm})\end{array}$ & $\begin{array}{l}\text { Year-ring } \\
\text { counts }\end{array}$ & $\begin{array}{l}\text { Diameter } \\
(\mathrm{cm})\end{array}$ & $\begin{array}{l}\text { Year-ring } \\
\text { counts }\end{array}$ & $\begin{array}{l}\text { Diameter } \\
(\mathrm{cm})\end{array}$ & $\begin{array}{c}\text { Year-ring } \\
\text { counts }\end{array}$ \\
\hline 1 & $6-8$ & 2.55 & 10 & 2.23 & 19 & 1.91 & 19 \\
\hline 2 & $8-10$ & 3.02 & 15 & 2.86 & 19 & 2.86 & 31 \\
\hline 3 & 10-12 & 3.66 & 18 & 3.50 & 21 & 3.66 & 33 \\
\hline 4 & $12-14$ & 4.30 & 16 & 3.98 & 26 & 3.98 & 37 \\
\hline 5 & $14-16$ & 4.93 & 19 & 4.93 & 34 & 4.93 & 27 \\
\hline 6 & 16-18 & 5.57 & 13 & 5.09 & 30 & 5.25 & 35 \\
\hline 7 & 18-20 & 6.21 & 15 & 6.37 & 34 & 6.21 & 29 \\
\hline 8 & $20-25$ & 7.00 & 20 & 7.80 & 41 & 7.00 & 45 \\
\hline 9 & & 7.80 & 24 & 7.96 & 39 & 7.96 & 39 \\
\hline 10 & $25-30$ & 9.23 & 20 & 9.23 & 32 & 8.12 & 30 \\
\hline 11 & & 9.55 & 21 & 9.39 & 42 & 8.44 & 40 \\
\hline 12 & 30-35 & 9.87 & 20 & 10.35 & 40 & 10.66 & 32 \\
\hline 13 & & 10.50 & 20 & 10.82 & 41 & 11.14 & 36 \\
\hline 14 & $35-40$ & 12.25 & 19 & 11.78 & 42 & 11.78 & 20 \\
\hline 15 & & 12.57 & 25 & 12.41 & 49 & 12.41 & 26 \\
\hline 16 & $40-45$ & 13.05 & 26 & 13.69 & 45 & 13.21 & 49 \\
\hline 17 & & 14.16 & 17 & 13.85 & 47 & 13.53 & 26 \\
\hline 18 & $45-50$ & 14.64 & 24 & 14.96 & 49 & 15.28 & 36 \\
\hline 19 & & 14.80 & 22 & 15.28 & 49 & 15.92 & 46 \\
\hline 20 & $50-60$ & 16.55 & 22 & 16.55 & 45 & 16.55 & 37 \\
\hline 21 & & 16.87 & 29 & 17.35 & 49 & 18.94 & 34 \\
\hline
\end{tabular}

et al. 1986). Since the solitary individuals of the studied successional habitat are subjected to a very uniform aerial environment, soil properties can be the main factors responsible for the mosaic-like local habitat differences.

Though the fate of a certain individual at the successional habitat can vary in a wide range, however at the population level this habitat offers much better conditions for growth of Fraxinus ornus, than the pine plantation does. Taking slope angles of regression equations into account, trees grow $72 \%$ faster in average in the successional habitat than in the pine plantation. 


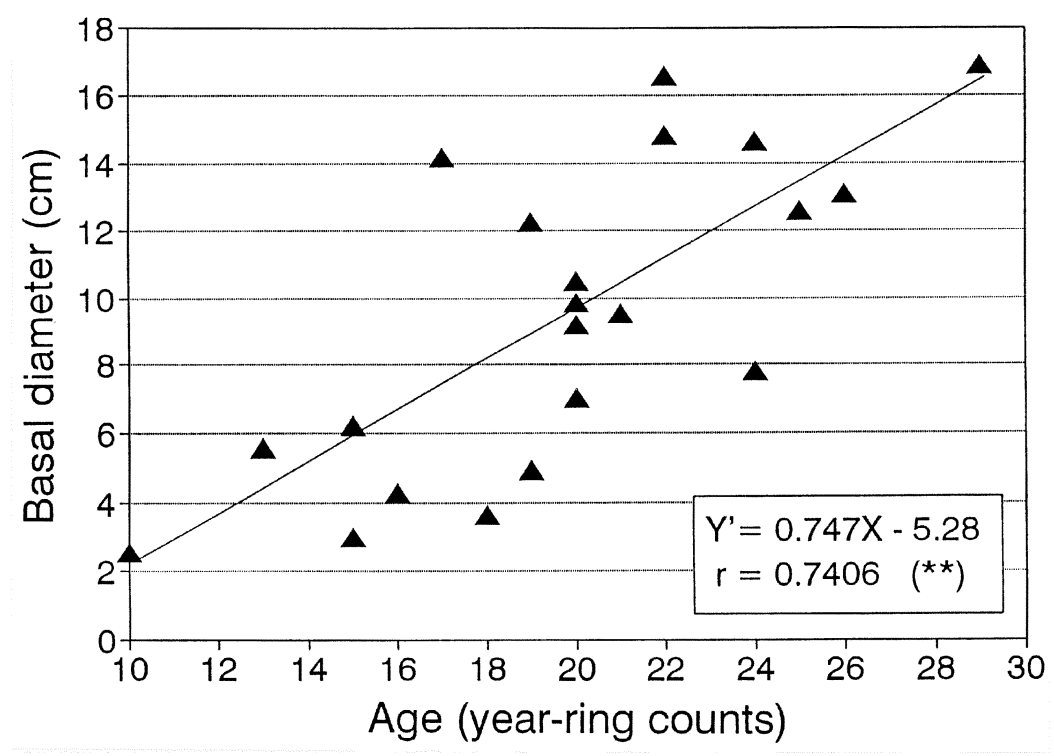

Fig. 1. Correlation between age and basal diameter of Fraxinus ornus individuals in a successional habitat $\left(\right.$ Nyakas Hill) ${ }^{* *}=$ significant at $\mathrm{p}<0.001$ level

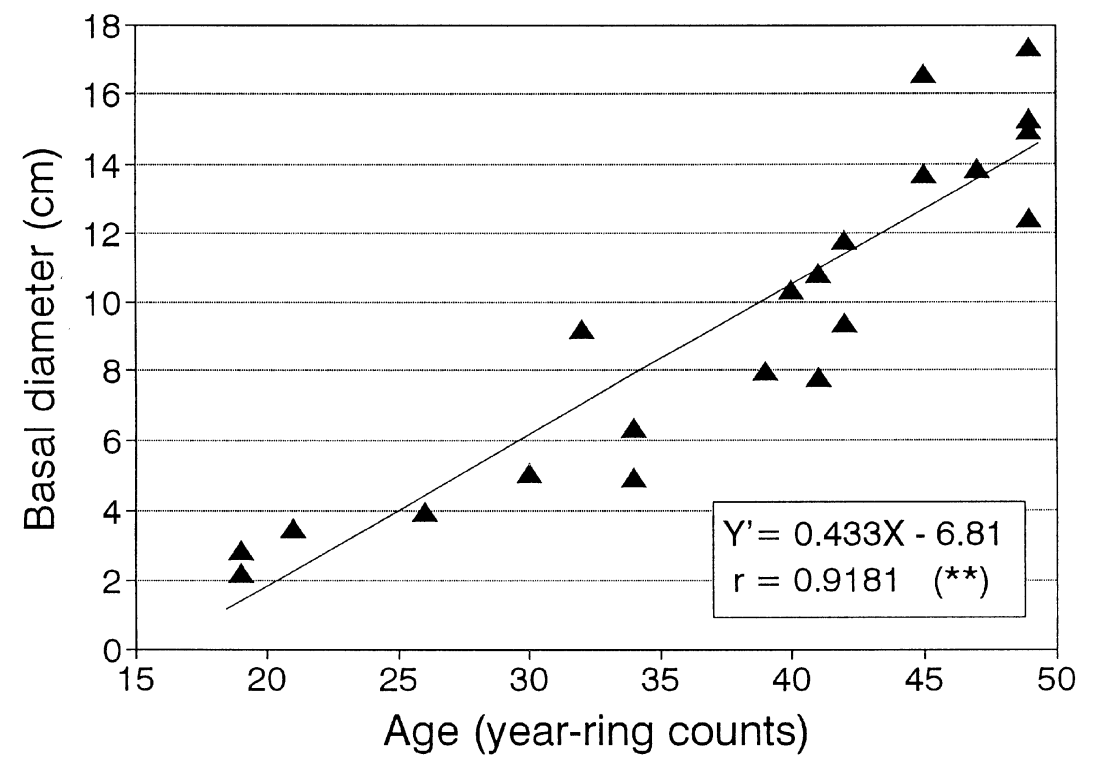

Fig. 2. Correlation between age and basal diameter of Fraxinus ornus individuals in a pine plantation (Zsíros Hill); ${ }^{* *}=$ significant at $\mathrm{p}<0.001$ level 


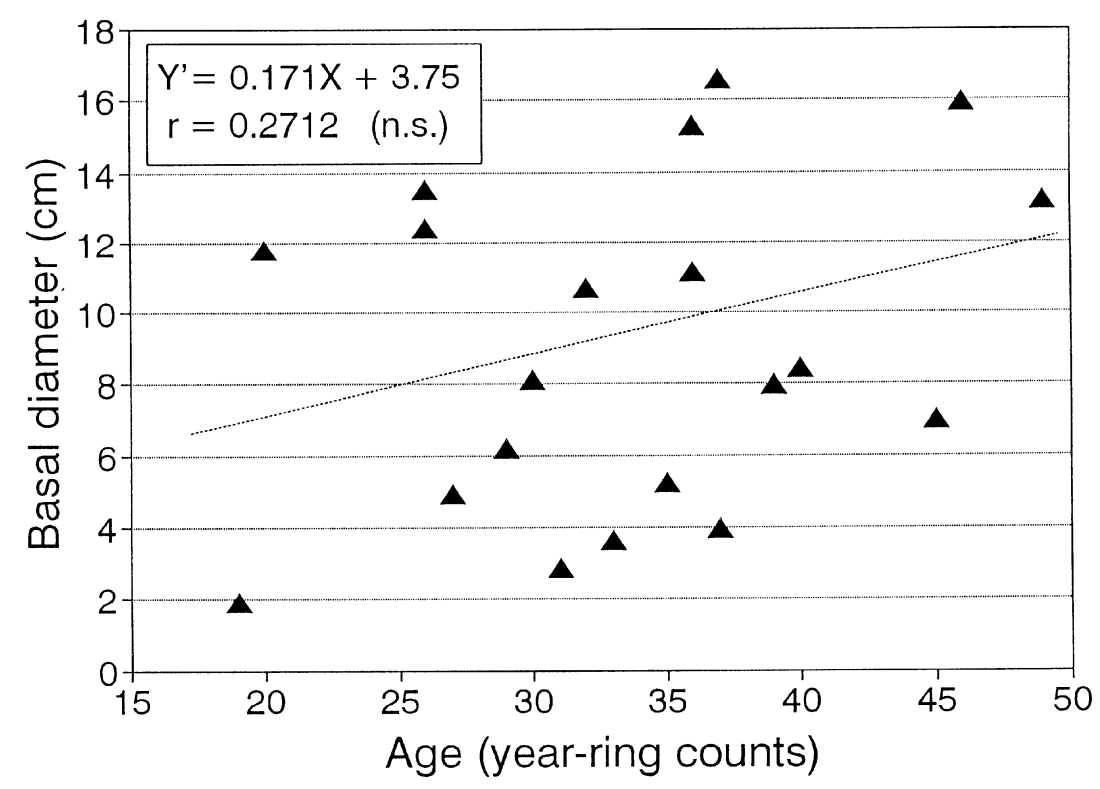

Fig. 3. Correlation between age and basal diameter of Fraxinus ornus individuals in a Cotino-Quercetum pubescentis community (Ördög-orom); n.s. = not significant

In case of the Cotino-Quercetum pubescentis community - what is considered as natural habitat of Fraxinus ornus - surprisingly the age and the basal diameter varied almost independently $(r=0.2712)$ (Fig. 3). In this habitat sometimes 10 or even 20 years differences occurred between individuals belonging the same circumference class, or from the other side 3-4-fold differences appeared in basal diameter of even-aged trees. Beside this, the average growing rate of manna ash (slope angle of the regression equation) was the lowest in this habitat.

These findings reflect to the highest variability of habitat conditions and to low productivity in general in the Cotino-Quercetum pubescentis community. Here the quality of a local habitat to what a certain individual meets is highly unpredictable because of the heterogeneity by both the aerial environment and soil properties. Undoubtedly, a considerable rate of morphological plasticity must characterize Fraxinus ornus, making it capable to maintain high density and to become dominant tree of a plant community in such extreme and chronically unproductive habitat like the studied one. It is assumed that certain physiological plasticity also contribute to the success of manna ash in surviving under very different conditions. 


\section{CONCLUSIONS}

For Fraxinus ornus growing in ecologically contrasting habitats the basal diameter of the trunk was found to be a good predictor of tree age where populations develop under a relatively uniform light regime, i.e. in a successional sun habitat (colonised grassland) or in the deep shade of a Pinus nigra plantation. However, the highly heterogeneous aerial and soil environments in the species' typical natural habitat (Cotino-Quercetum pubescentis scrub woodland) cause an uncoupling of age and trunk diameter. In addition, diameter growth is fastest in the least abiotically limited successional sun habitat.

Acknowledgements - Many thanks are due to Dóra Krasser and Sándor Barabás (MTA ÖBKI, Vácrátót) for their help during the field work. The project was supported by the European Commission (ENV4-CT97-0680) and the Hungarian Commission for Technological Development (OMFB EU-98-C6-072).

\section{REFERENCES}

Baonza, J., Gutiérrez, A. and Traba, J. (1995): Primeras citas de fresno florido, Fraxinus ornus L., en Burgos. - Anales Jardín Botánico de Madrid53(1): 128-129.

Bertová, L., Hlavacek, A., Holub, J., Jasicová, M., Sourková, M. and Zahradníková, K. (1984): Flóra Slovenska. IV/1. - VEDA, Bratislava, 443 pp. [in Slovakian]

Borhidi, A. (1956): Feketefenyveseink társulási viszonyai. (Zönologische Verhältnisse unserer Schwarzföhrenwälder.) - Bot. Közlem. 46(1-2): 275-285. [in Hungarian with German summary]

Borhidi, A. (1984): A Zselic erdei. (The forests of Zselic.) - Dunántúli Dolg. Term.tud. Sor. 4: 1-145. [in Hungarian with English summary]

Csontos, P., Horánszky, A., Kalapos, T. and Lőkös, L. (1996): Seed bank of Pinus nigra plantations in dolomite rock grassland habitats, and its implications for restoring grassland vegetation. - Annls hist.-nat. Mus. natn. Hung. 88: 69-77.

Debreczy, Zs. (1968): Der Flaumeichen-Hochwald (Orno-Quercetum pannonicum) des Balaton-Oberlandes. - Acta Bot. Hung. 14(3-4): 261-280.

Fekete, G. (1956): Die Vegetation des Velenceer Gebirges. - Annls hist.-nat. Mus. natn. Hung. 7: 343-362.

Fekete, G. (1959): Angaben zur Zönologie der moesischen Schwarzföhrenwälder. - Acta Bot. Acad. Sci. Hung. 5(3-4): 327-347.

Fekete, G. (1965): Die Waldvegetation im Gödöllőer Hügelland. - Akadémiai Kiadó, Budapest, 223 pp.

Grime, J. P., Crick, J. C. and Rincon, J. E. (1986): The ecological significance of plasticity. - In: Jennings, D. H. and Trewavas, A. J. (eds): Plasticity in Plants. Company of Biologists, Cambridge, U.K., pp. 5-19. 
Horánszky, A. (1964): Die Wälder des Szentendre-Visegráder Gebirges. - Akadémiai Kiadó, Budapest, $288 \mathrm{pp}$.

Horvat, I., Glavač, V. and Ellenberg, H. (1974): Vegetation Südosteuropas. - Gustav Fischer Verlag, Stuttgart, 768 pp.

Horváth, A. O. (1972): Die Vegetation des Mecsekgebirges und Seiner Umgebung. - Akadémiai Kiadó, Budapest, 376 pp.

Isépy, I. (1968): Szurdokerdők és törmeléklejtő-erdők a Vértes-hegységben. (Schlucht- und Schuttabhangwälder in Vértes-Gebirge.) - Bot. Közlem. 55(3): 199-204. [in Hungarian with German summary]

Kárpáti, Z. (1958): Die variabilität der Manna-Esche (Fraxinus ornus L.). - Acta Bot. Hung. 4(1-2): 93-112.

Kárpáti, Z. E. (1970): Eine kritisch-taxonomische Übersicht der in Europa wildwachsenden Eschen-Arten und deren Unterarten. - Feddes Repertorium (Berlin) 81(1-5): 171-186.

Lorimer, C. G., Dahir, S. E. and Singer, M. T. (1999): Frequency of partial and missing rings in Acer saccharum in relation to canopy position and growth rate. - Plant Ecology 143: 189-202.

Meusel, H., Jäger, E., Rauschert, S. and Weinert, E. (eds) (1978): Vergleichende Chorologie der Zentraleuropäischen Flora. Band II. - Gustav Fischer Verlag, Jena.

Mészáros-Draskovits, R. (1967): A Linum dolomiticum Borb. cönológiai viszonyai. (Zönologische Verhältnisse von Linum dolomiticum Borb.). - Bot. Közlem. 54(3): 193-201. [in Hungarian with German summary]

Penksza, K., Benyovszky, B. M., Ötvös, E. and Asztalos, J. (1995): Phytosociological studies of the cliff Fehér-szirt, near Kesztölc, Hungary. - Acta Bot. Hung. 39(1-2): 71-95.

Penksza, K., Káder, F. and Benyovszky, B. M. (1996): Vegetációtanulmány a Balatonalmádi (Vörösberény) melletti Megye-hegyről. (Phytosociological studies on vegetation of Megye Hill near Balatonalmádi (Vörösberény), Hungary). - Bot. Közlem. 83(1-2): 71-90.

Soó, R. (1966): Synopsis Systematico-Geobotanica Florae Vegetationisque Hungariae II. - Akadémiai Kiadó, Budapest, 655 pp. (in Hungarian)

Sváb, J. (1981): Biometriai módszerek a kutatásban. (Biometrical methods in research work.) Third, revised version. - Mezőgazdasági Kiadó, Budapest, 557 pp. [in Hungarian with English summary]

Szabó, M. (1939): Verbreitung der offizinellen Pflanzenarten in Ungarn. - Acta Geobot. Hung. 2: 229-233.

Tamás, J. (1997): A növényzet regenerálódása leégett feketefenyvesek helyén, dolomiton. (Regeneration of dolomite grasslands after burning of Austrian pine plantations.) - ELTE szakdolgozat, Budapest, 80 pp. [in Hungarian]

Thébaud, C. and Debussche, M. (1991): Rapid invasion of Fraxinus ornus L. along the Hérault River system in southern France: the importance of seed dispersal by water. $-J$. Biogeogr. 18: 7-12.

Zólyomi, B. (1958): Budapest és környékének természetes növénytakarója. (Natural vegetation of Budapest and its surroundings.) - In: Pécsi, M. (ed.): Budapest természeti képe. Akadémiai Kiadó, Budapest, pp. 508-642. [in Hungarian] 